\title{
The Effect of Teamwork on Employee Performance in Some Selected Private Banks in Mogadishu-Somalia
}

\author{
Adam ABDULLE ${ }^{\text {iD }}$ aelgin AYDINTAN ${ }^{\text {i }}{ }_{b}$ \\ a Gazi University, Institute of Social Sciences, Faculty of Economics and Administrative Sciences, Ankara, Turkey. adam.isak@hbv.edu.tr \\ b Ankara Hacı Bayram Veli University, Faculty of Economics and Administrative Sciences, Ankara, Turkey. belgin.aydintan@hbv.edu.tr
}

\begin{tabular}{|c|c|}
\hline ARTICLE INFO & ABSTRACT \\
\hline $\begin{array}{l}\text { Key Words: } \\
\text { Teamwork } \\
\text { Employee performance } \\
\text { Team members' trust } \\
\text { Team members' cohesiveness } \\
\text { Team members' spirit } \\
\text { Team members' knowledge } \\
\text { sharing } \\
\text { Received } 3 \text { March } 2019 \\
\text { Revised } 17 \text { July } 2019 \\
\text { Accepted } 20 \text { Auğust } \\
\text { Article Classification: } \\
\text { Research Article }\end{array}$ & $\begin{array}{l}\text { Purpose - This study was intended to examine the effect of teamwork on employee performance } \\
\text { in some selected private banks in Mogadishu-Somalia. Therefore, the research has the following } \\
\text { specific objectives: To assess the effect of team members' trust, cohesiveness, spirit or "esprit de } \\
\text { corps", and knowledge sharing on employee performance in the study's selected private banks in } \\
\text { Mogadishu-Somalia, namely; Dahabshiil, Premier, and Amal banks. } \\
\text { Design/methodology/approach - This study adopted a descriptive research design to describe the } \\
\text { characteristics and behaviors of the selected target population. The target population of this study } \\
\text { was } 500 \text { respondents with a sample size of } 222 \text { employees who work at the study's selected } \\
\text { private banks. The research data was collected using a structured survey as the research } \\
\text { instrument of this study. To assess the internal consistency of the research data reliability and } \\
\text { validity tests were conducted via SPSS (Statistical Package for Social Sciences). Furthermore, the } \\
\text { data of this study was analyzed utilizing model summary, analysis of variance (ANOVA), } \\
\text { coefficient of determination (R²) and regression coefficients to determine the effect of teamwork on } \\
\text { employee performance in the study's selected private banks in Mogadishu-Somalia. } \\
\text { Findings - The current study used teamwork measures such as trust, cohesiveness, spirit, and } \\
\text { knowledge sharing among team members while determining the effect of these independent } \\
\text { variables on employee performance. Hence, this study found that all teamwork measures of the } \\
\text { study which are; trust, cohesiveness, spirit or "esprit de corps", and knowledge sharing among } \\
\text { members of the team have a positive and significant impact on employee performance of the } \\
\text { study's selected private banks in Mogadishu-Somalia. } \\
\text { Discussion - From the study data analysis, interpretations, and findings, the researchers drew } \\
\text { study conclusions proposing that the private banks in Mogadishu-Somali should create an } \\
\text { environment that assists teamwork to enhance trust, cohesiveness, spirit, and knowledge sharing } \\
\text { among their teams since this, in turn, will increase the performance of their employees as the } \\
\text { findings of this study indicate. }\end{array}$ \\
\hline
\end{tabular}

\section{INTRODUCTION}

This paper has investigated the effect of teamwork on employee performance in some selected private banks in Mogadishu-Somalia. A team is a word and concept well known to everyone. Teams have existed for many years, they are the subject of countless books, and have been celebrated across different countries and civilizations (Katzenbach \& Smith, 1993). The concept of teamwork is as old as human beings, and many firms practice it in their different divisions "e.g. manufacturing and marketing processes". Furthermore, there are different types of teams such as management teams, production teams, marketing teams; sales teams, virtual teams or even sometimes we can describe the entire organization as a team. Collaboration is commonly acknowledged as a helpful force for teamwork in any firm since it helps workmates to work together towards achieving the organizational performance-related goals. Teams assist its members to inspire each other and to surge advantages from cooperative of working together as a team. Besides, working together with other individuals also allows coworkers to better recognize the significance of 


\section{A. Abdulle - B. Aydintan 11/3 (2019) 1589-1598}

teamwork on their performance. Thus, firms should encourage an outlook and attitude of teamwork to gain its benefits (Agarwal \& Adjirackor, 2016).

\subsection{Problem Statement of the Study}

There is inadequate research support to proof the effect of teamwork on employee performance within firms, and the subject did not attract sufficient research interest. This might be seen from a rarely obtainable empirical study on this topic. Furthermore, the common independent variables or teamwork measures that the previous research scholars used to foresee the effect of teamwork on employee performance, ranges from interpersonal skills to communication without focusing the capabilities or abilities of the team members, team members' spirit/esprit de corps, recognition and reward as teamwork measures that can better forecast the effect of teamwork on employee performance (Arinze et al., 2018).

Furthermore, Khan \& Mashikhi, (2017) conducted a study to investigate the impact of teamwork on employees' performance of Oman banking sector and they argued that, as result of the rise in local and global banks in the region, it has become hard for the banks to attract and retain their customers. For this reason, currently, the banking sector is striving to increase their human capital or employee performance to achieve maximum efficiency and retain their customers whether internal "employees" or external "buyers/ consumers".

In the context of Somalia as far as the researchers of this study are concerned, there is no research about the effect of teamwork on employee performance - specifically in the private banking sector in MogadishuSomalia. Therefore, this recognizable gap encouraged the researchers of the current study to carry out this investigation to highlight how teamwork measures such as team members' trust, team members' spirit, team members' cohesiveness, and team members' knowledge sharing affect the employee performance in the study's selected private banks in Mogadishu-Somalia.

\subsection{Objectives of the Study}

The main objective of the study was to examine the effect of teamwork on employee performance in some selected private banks in Mogadishu-Somalia.

The specific objectives of the research were as follows:

1. To examine the effect of team members' trust on employee performance in Mogadishu private banks, Somalia.

2. To investigate the effect of team members' cohesiveness on employee performance in Mogadishu private banks, Somalia.

3. To analyze the effect of team members' spirit "esprit de corps" on employee performance in Mogadishu private banks, Somalia.

4. To highlight the effect of team members' knowledge sharing on employee performance in Mogadishu private banks, Somalia.

\subsection{Research Hypotheses}

To guide the objectives of the research and to strengthen the analysis, the hypotheses of this study were formulated as the following:

$\mathrm{HO}_{1}$ : Team members' trust has no significant effect on employee performance in Mogadishu private banks, Somalia.

$\mathrm{H}_{1}$ : Team members' trust has a significant effect on employee performance in Mogadishu private banks, Somalia.

$\mathrm{HO}_{2}$ : Team members' cohesiveness has no significant effect on employee performance in Mogadishu private banks, Somalia.

$\mathrm{H}_{2}$ : Team members' cohesiveness has a significant effect on employee performance in Mogadishu private banks, Somalia.

$\mathrm{HO}_{3}$ : Team members' spirit "esprit de corps" has no significant effect on employee performance in Mogadishu private banks, Somalia.

$\mathrm{H1}_{3}$ : Team members' spirit "esprit de corps" has a significant effect on employee performance in Mogadishu private banks, Somalia.

$\mathrm{HO}_{4}$ : Team members' knowledge sharing has no significant effect on employee performance in Mogadishu private banks, Somalia. 
$\mathrm{H}_{4}$ : Team members' knowledge sharing has a significant effect on employee performance in Mogadishu private banks, Somalia.

\section{LITERATURE REVIEW}

Organizations around the globe are realizing the importance of teamwork and how it leads to high performance within their organizations. Firms whether they are public or private, large or small, service or manufacturing use different resources such as capital resources, physical resources, and most importantly human resources, to achieve their performance goals and objectives. Human resource managers are responsible for looking after the employees of the firm by motivating, training and developing, solving their problems and helping them build a better relationship not only with the employer but also among themselves as a team. Human resources are the best assets that every organization has to use to accomplish their business goals. Team members have different skills such as technical, interpersonal, problem-solving, and decision-making skills; these skills are complementary to each other. If all members of the team have the same ideas, opinions, skills or knowledge they would not be innovation in the organizations anymore. Thus, employees need to appreciate their diversity, whether their different skills, culture, views, etc., because if they do so, this could help them to work together brilliantly and this in return enhances their performance and the firm's performance as a whole. Therefore, organizations need to create an atmosphere that fosters teamwork to enjoy the greater benefits of their teams. According to Agarwal and Adjirackor, (2016) companies may be able to increase their employee performance by enhancing the capacity of their teams, which in return will increase the performance level of their employees.

Kemanci (2018) writes that the effect of teamwork in enhancing employee performance in the era of increased competition cannot be overstressed. Teamwork improves the efficiency and effectiveness of the teams. It provides the team the spirit of possessions and it also allows them to put their greatest effort in accomplishing organizational performance-related goals. Additionally, teamwork brings about different skills and talents, which in turn inspires and helps individual development within the team.

Manzoor et al., (2011) conducted a study to assess the impact of teamwork on employee performance of the Higher Education Department of Khyber Pakhtoon Khawa, Peshawar Province of Pakistan. In their study, the scholars used numerous teamwork measures such as team members' spirit, team members' trust, and recognition and reward to foresee the effect of these teamwork measures or independent variables have on employee performance. Besides, as a study instrument, the researchers of this study employed selfadministered surveys, which was distributed to four government degree colleges of boys and girls located in Peshawar and Kohat region. Furthermore, the scholars used a mixed of regression and correlation analyses to explain and analyze research data. Correlation analysis was aimed to determine the association between the variables of the study, whereas the regression analysis was executed to examine the effect of teamwork on employee performance of Higher Education Department of Khyber Pakhtoon Khawa. The researchers concluded their study that, there is a strong proof which indicates, teamwork measures which are; team members' spirit, team members' trust, and recognition and rewards have a positive and significant influence on employee performance of Higher Education Department of Khyber Pakhtoon Khawa (KPK), Peshawar Province of Pakistan.

Khan \& Mashikhi (2017) carried out a study on the same subject, the main objective of the research was to determine the effect of teamwork on employee performance of Oman banking sector. The data of the study gathered from one hundred twenty (120) employees who are working at a bank in Oman. Furthermore, the researchers of this study used various statistical tests such as correlation and regression analyses. The former analysis was meant to examine the relationship between teamwork and employee performance, while the latter analysis was intended to prove if the teamwork measure or independent variable, which in this case was team members' knowledge sharing effects on employee performance. Lastly, based on the research data analysis, the investigators of the study discovered that the teamwork has a significant positive effect on employee performance of the study's selected bank.

The current study used various teamwork measures or independent variables to discover the effect of teamwork on employee performance of the study's selected private banks in Mogadishu-Somalia, these measures included; team members' trust, team members' cohesiveness, team members' spirit/esprit de corps and team members' knowledge sharing.

Furthermore, to determine how these independent variables or teamwork measures affect the dependent variable, the researchers of this study designed a conceptual framework or research model based on the previous literature on the subject and the researchers' understanding of the matter. Therefore, in this study the impact of teamwork on employee performance can be conceptualized as follows: 


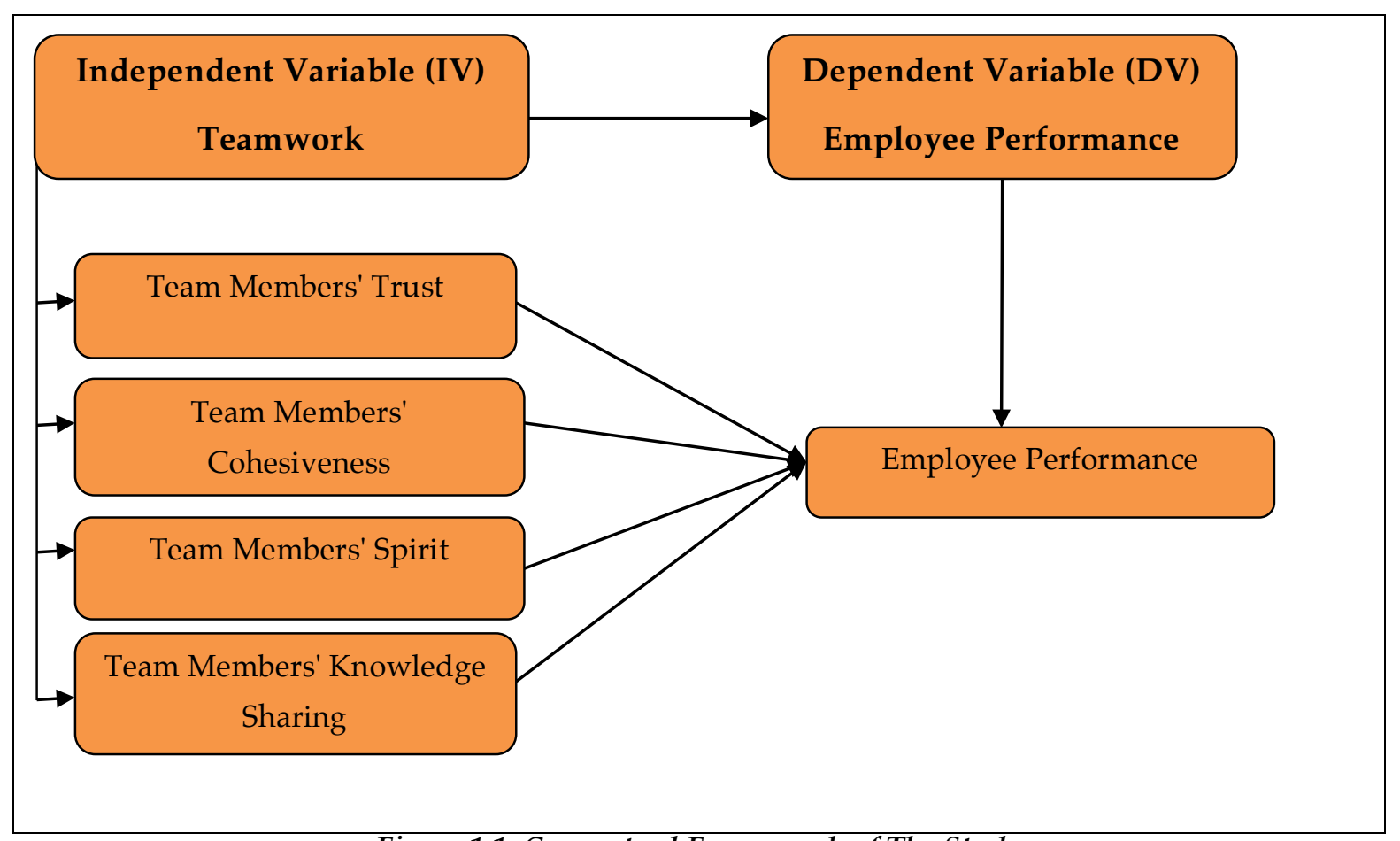

Figure 1.1. Conceptual Framework of The Study

\section{METHODOLOGY}

\subsection{Research Design}

This study adopted a quantitative research method to investigate the effect of teamwork on employee performance in the study's selected private banks in Mogadishu-Somalia. This methodology was chosen since it can quantitatively identify and summarizes the features of the collected research data.

\subsection{Research Population}

The target population of this study comprised of 500 respondents with a sample size of 222 employees who work at the study's selected private banks, namely; Dahabshiil Bank, Premier Bank, and Amal Bank in Mogadishu-Somalia.

\subsubsection{Sample Size and Sample Technique}

The sample size of 222 respondents was drawn from the target population, which are the employees of the selected private banks. The respondents of this study include; junior employees, officers, managers, and directors of the study's selected private banks. Additionally, the researchers used Slovin's formula to calculate the study sample size.

$$
\begin{aligned}
\mathrm{n}=\mathrm{N} / 1+\mathrm{N}(\alpha) 2 & \\
\mathrm{n}=500 / & (1+500(0.05)) 2 \\
= & 222
\end{aligned}
$$

The table below 3.1 shows the distribution of the sample size to the study's selected private banks.

Table 3.1. Distribution of sample size to the selected private banks

\begin{tabular}{|l|c|c|}
\hline Banks & Sample size & Percent (\%) \\
\hline Dahabshiil Bank & 92 & $41.4 \%$ \\
\hline Premier Bank & 70 & $31.5 \%$ \\
\hline Amal Bank & 60 & $27 \%$ \\
\hline Total & 222 & $100 \%$ \\
\hline
\end{tabular}

Furthermore, the kind of sample that the scholars of study used was, a probability sample specifically stratified random sample technique. This method involves the segmentation or breakdown of the study population into smaller teams or groups known as strata. The researchers selected this sampling method since it allows for getting relevant and useful information to the study. 


\subsection{Research Instrument}

A structured questionnaire was the major tool used to gather the research needed data for this study since it can increase the correctness of the collected research data. Also, this instrument was seen as appropriate for the study as the time of collecting the research data was limited. Furthermore, the kind of questionnaire that the researchers of this study employed were five points Likert scale. The Likert scale consists of five scales, which are: strongly agree, agree, disagree, strongly disagree and neutral. This scale ranges from "strongly disagree" on one end to "strongly agree" on the other with "neither agree nor disagree/neutral" in the middle.

\subsection{Data Gathering Procedure}

Before embarking on research data collection from respondents, the researchers of this study requested permission from relevant authorities of the study's selected private banks. When the researchers got permission from the management of these banks that they collect the needed primary research data for the study, they distributed the study surveys with closed letter of introduction to the respondents who work at the various departments of the study's selected private banks.

\subsection{Validity and Reliability of the Study}

\subsubsection{Reliability test of the study}

The researchers of this study conducted a pilot study to pre-test the reliability and validity of data gathered by using a questionnaire. Then, the researchers of this study employed Cronbach Alpha to examine the internal consistency of the data gathered from the participants of this study. This process involved distributing 22 questionnaires, which represents $10 \%$ of the total respondents to 22 employees who work at the study's selected private banks. Thus, all variables of the research gained high inside reliability as displayed in table 3.2 below shows.

Table 3.2. Reliability Statistics

\begin{tabular}{|l|c|c|c|}
\hline \multicolumn{1}{|c|}{ Variables } & N of Items & Cronbach's Alpha & Remarks \\
\hline Team Members' Trust & 6 & 0.799 & Accepted \\
\hline Team Members' Cohesiveness & 6 & 0.791 & Accepted \\
\hline Team Members' Spirit & 6 & 0.822 & Accepted \\
\hline Team Members' Knowledge Sharing & 6 & 0.828 & Accepted \\
\hline Employee Performance & 5 & 0.822 & Accepted \\
\hline
\end{tabular}

\subsubsection{Validity test of the study}

To check the validity of the study data, the scholars of the current research employed factor analysis, particularly Kaiser-Mayor-Oklin (KMO) \& Bartlett's Test of Sphericity measures of sampling adequacy. $\mathrm{KMO}$ and Bartlett Test of Sphericity measures are used to determine the appropriateness of factor analysis. Generally, $0<\mathrm{KMO}<1$. If $\mathrm{KMO}>0.5$, this means that the sample is adequate. According to table 3.3 below, teamwork KMO and Bartlett's Test of Sphericity were significant as their values were equal to (0.000), which less than 0.05. Additionally, teamwork KMO measure of sampling adequacy is 0.899 and this indicates that teamwork measures or dependent variables of the study, which are; team members' trust, team members' cohesiveness, team members' spirit, and team members' knowledge sharing are homogeneous and suitable for factor analysis since their value is greater than 0.5 or even 0.65 as some scholars argue. Besides, Bartlett's test of Sphericity displays the value of test statistic as 0.000 , which in this case is also less than 0.05 ; hence it is under the acceptable or significant value. Based on Kaiser-Mayor-Oklin (KMO) \& Bartlett's Test of Sphericity analyses, factor analysis is considered as an appropriate technique for further analyses of the study data as table 3.3 below demonstrates.

Table 3.3. Teamwork KMO and Bartlett's Test

\begin{tabular}{|l|l|l|}
\hline \multicolumn{2}{|c|}{ KMO and Bartlett's Test } \\
\hline Kaiser-Meyer-Olkin Measure of Sampling Adequacy. & 0.899 \\
\hline \multirow{3}{*}{ Bartlett's Test of Sphericity } & Approx. Chi-Square & 2183.384 \\
\cline { 2 - 3 } & Df & 276 \\
\cline { 2 - 3 } & Sig. & 0.000 \\
\hline
\end{tabular}

As table 3.4 below displays, employee performance KMO and Bartlett's test were significant as their value were (0.000), which is less than 0.05. Additionally, employee performance Kaiser-Meyer-Olkin measure of sampling adequacy is 0.804 , which greater than 0.5 or 0.65 as several academics claims and this indicates that sufficient items for each measure or variable are used in the study are homogeneous and suitable for factor analysis. 
Table 3.4. Employee Performance KMO and Bartlett's Test

\begin{tabular}{|l|l|l|}
\hline \multicolumn{2}{|c|}{ KMO and Bartlett's Test } \\
\hline Kaiser-Meyer-Olkin Measure of Sampling Adequacy. & 0.804 \\
\hline \multirow{3}{*}{ Bartlett's Test of Sphericity } & Approx. Chi-Square & 358.184 \\
\cline { 2 - 3 } & Df & 10 \\
\cline { 2 - 3 } & Sig. & 0.000 \\
\hline
\end{tabular}

Factor loadings analyses were also employed in this study. In this regard, team members' trust scale items were composed of 6 with factor loads ranging from 0.783-0.526. Team members' cohesiveness scale statements were composed of 6 with factor loads ranging from 0.785-0.549. Additionally, team members' spirit/esprit de corps scale questions were comprised of 6 with factor loads ranging from 0.786-0.675. Furthermore, team members' knowledge sharing scale statements consisted of 6 with factor loads ranging from $0.768-0.711$. Thus, all teamwork measures or independent variables' factors loads, there is no factor load whose value is less than 0.30 and this denotes that the factor loads are close to each other, therefore no substance was excluded from the study as table 3.5 below exhibits.

Table 3.5. Teamwork Factor loadings

\begin{tabular}{|c|c|c|c|}
\hline Variables & Statements & Factor Loadings & Remarks \\
\hline \multirow{6}{*}{ Team Members' Trust } & TTM1 & 0.711 & Valid \\
\hline & TTM2 & 0.783 & Valid \\
\hline & TTM3 & 0.746 & Valid \\
\hline & TTM4 & 0.761 & Valid \\
\hline & TTM5 & 0.726 & Valid \\
\hline & TTM6 & 0.526 & Valid \\
\hline \multirow{6}{*}{ Team Members' Cohesiveness } & TMC1 & 0.731 & Valid \\
\hline & TMC2 & 0.785 & Valid \\
\hline & TMC3 & 0.759 & Valid \\
\hline & TMC4 & 0.684 & Valid \\
\hline & TMC5 & 0.682 & Valid \\
\hline & TMC6 & 0.549 & Valid \\
\hline \multirow{6}{*}{ Team Members' Spirit } & TMS1 & 0.675 & Valid \\
\hline & TMS2 & 0.712 & Valid \\
\hline & TMS3 & 0.760 & Valid \\
\hline & TMS4 & 0.786 & Valid \\
\hline & TMS5 & 0.755 & Valid \\
\hline & TMS6 & 0.679 & Valid \\
\hline \multirow{6}{*}{ Team Members' Knowledge Sharing } & TMKS1 & 0.721 & Valid \\
\hline & TMKS2 & 0.768 & Valid \\
\hline & TMKS3 & 0.732 & Valid \\
\hline & TMKS4 & 0.739 & Valid \\
\hline & TMKS5 & 0.735 & Valid \\
\hline & TMKS6 & 0.711 & Valid \\
\hline
\end{tabular}

Furthermore, employee performance scale was composed of 5 items with factor loads ranging from 0.810 0.720. Thus, all employee performance factors loads, there is no factor load whose values is less than 0.30 , therefore, thus indicating that the factor loads are close to each other, therefore no substance was excluded from the study as table 3.6 below displays.

Table 3.6. Employee Performance Factor loadings

\begin{tabular}{|l|l|l|l|}
\hline \multirow{4}{*}{ Variables } & Statements & Factor Loadings & Remarks \\
\hline \multirow{4}{*}{ Employee Performance } & EP1 & 0.776 & Valid \\
\cline { 2 - 4 } & EP2 & 0.796 & Valid \\
\cline { 2 - 4 } & EP3 & 0.810 & Valid \\
\cline { 2 - 4 } & EP4 & 0.720 & Valid \\
\cline { 2 - 4 } & EP5 & 0.727 & Valid \\
\hline
\end{tabular}




\section{A. Abdulle - B. Aydıntan 11/3 (2019) 1589-1598}

In addition to the above validity and reliability analyses, the study questionnaire was designed in a way that incorporates all the set research objectives; it is also prepared such a simple and understandable way to help the respondents to provide relevant data for the research to ensure validity and reliability of the study.

\section{RESULTS}

\subsection{Questionnaire Response Rate}

This study aimed to determine the effect of teamwork on employee performance. Therefore, quantitative data was gathered from the employees in the study's some selected private banks in Mogadishu-Somalia through employing survey instrument. The total questionnaires distributed to the study participants were 222. Almost all the distributed questionnaires were returned to the researchers, however, 11 questionnaires, which represent a response rate of $5 \%$ of the total responses were rejected due to defective, incorrect and incomplete responses given by the participants, whereas usable and non-defective responses were 211, which is equivalent to a response rate of $95 \%$ of the total responses as table 4.1 below demonstrates.

Table 4.1. Questionnaire Response Rate

\begin{tabular}{|l|c|c|}
\hline Survey Method (Questionnaires) & Frequency & Percent (\%) \\
\hline Total questionnaires distributed & 222 & $100 \%$ \\
\hline Returned questionnaires & 222 & $100 \%$ \\
\hline Unreturned questionnaires & 0 & $0 \%$ \\
\hline Defective response and rejected & 11 & $5 \%$ \\
\hline Usable and non-defective responses & 211 & $95 \%$ \\
\hline
\end{tabular}

\subsection{Regression Analysis}

The research employed multiple regression analysis to analyze the impact of teamwork on employee performance in the study's selected private banks in Mogadishu-Somalia. To do so, the researchers used teamwork measures or independent variables such as members of the teams' trust, cohesiveness, spirit/esprit de corps, and knowledge sharing to determine their effect on the dependent variable, which is the employee performance in the study's selected private banks in Mogadishu-Somalia. Thus, the multiple regression equation was as follows:

$$
Y=\beta 0+\beta 1 X 1+\beta 2 X 2+\beta 3 X 3+\beta 4 X 4+\varepsilon
$$

Where:

$$
\begin{aligned}
& Y=\text { Employee Performance “Dependent Variable" } \\
& \beta 0=\text { Intercept of the regression line } \\
& \beta 1-\beta 4=\text { Partial regression coefficient of the Independent Variables } \\
& \text { X1 = Team Members' Trust (TMT) } \\
& X 2=\text { Team Members' Cohesiveness (TMC) } \\
& \text { X3 = Team Members' Spirit/ Esprit De Corps (TMS/TMEDC) } \\
& X 4=\text { Team Members' Knowledge Sharing (TMKS) } \\
& \varepsilon=\text { error term or stochastic term }
\end{aligned}
$$

OR:

$$
\mathrm{EP}=\beta 0+\beta 1 \mathrm{TMT}+\beta 2 \mathrm{TMC}+\beta 3 \mathrm{TMS} / \mathrm{TMEDC}+\beta 4 \mathrm{TMKS}+\varepsilon \ldots . \text { (2) }
$$

Where:

$$
\begin{aligned}
& \text { EP = Employee Performance } \\
& \beta 0=\text { Intercept of the regression line } \\
& \beta 1-\beta 4=\text { Partial regression coefficient of the Independent Variables } \\
& \text { TMT = Team Members' Trust } \\
& \text { TMC = Team Members' Cohesiveness } \\
& \text { TMS / TMEDC = Team Members' Spirit / Esprit de Corps } \\
& \text { TMKS= Team Members' Knowledge Sharing } \\
& \varepsilon=\text { error term or stochastic term }
\end{aligned}
$$

\subsubsection{Coefficient of Determination $\left(R^{2}\right)$}

The table 4.2 underneath displays coefficient of determination $\left(\mathrm{R}^{2}\right)$, which measures how far these teamwork measures or independent variables: Team members' trust, team members' cohesiveness, team members' spirit/esprit de corps, and team members' knowledge sharing explain the dependent variables, which is 


\section{A. Abdulle - B. Aydıntan 11/3 (2019) 1589-1598}

employee performance in this study. To test study hypotheses, the researchers conducted a standard multiple regression analysis where employee performance was the dependent variable and the other four teamwork variables were independent variables or teamwork measures of the research. In this analysis, there are two important things to consider which are; $R$ and $R$ Square.

$\mathrm{R}$ is the Regression Coefficient, which is according to the study's results is 0.709 or $71 \%$, and it indicates the existence of a relationship between the two variables: teamwork and employee performance. On the other hand adjusted $\mathrm{R}^{2}$ which is 0.493 or $49.3 \%$ demonstrates that teamwork measures or independent variables: team members' trust, team members' cohesiveness, team members' spirit, team members' knowledge sharing explain about 0.493 or $49.3 \%$ of variations in employee performance of study's selected private banks in Mogadishu-Somalia. Thus, this implies that the other $50.7 \%$ is attributed to other factors, which influence employees' performance but have not been considered in this study.

Table 4.2. Coefficient of Determination $\left(\mathbf{R}^{2}\right)$

\begin{tabular}{|c|l|l|l|l|}
\hline \multicolumn{4}{|c|}{ Model Summary } \\
\hline Model & $\mathrm{R}$ & R Square & Adjusted R Square & Std. Error of the Estimate \\
\hline 1 & $0.709 \mathrm{a}$ & 0.503 & 0.493 & 0.69421 \\
\hline $\begin{array}{l}\text { a.Predictors: (Constant), Team Members' Trust, Team Members' Cohesiveness, Team Members' Spirit, Team } \\
\text { Members' Knowledge Sharing }\end{array}$
\end{tabular}

\subsubsection{Analysis of Variance (ANOVA)}

Table 4.3 below shows the results of analysis of variance (ANOVA), in the table it is clear that the whole standard multiple regression model of teamwork variables: team members' trust, team members' cohesiveness, team members' spirit, team members' knowledge sharing is significant in predicting employee performance in the study's selected private banks in Mogadishu-Somalia. The ANOVA results show that Fvalue is 52.097 and it is significant at the 0.000 since it is less than the study's significance level which is 0.05 , thus this reveals that, the overall regression model is statistically significant, valid and fit. Therefore, it can be concluded that teamwork measures of this study: team members' trust, team members' cohesiveness, team members' spirit, team members' knowledge sharing have a positive significant association with the employee performance of the study's selected private banks.

Table 4.3. Analysis of Variance

\begin{tabular}{|c|l|l|c|c|c|c|}
\hline \multicolumn{2}{|c|}{ ANOVA $^{2}$} & Sig. \\
\hline \multicolumn{2}{|c|}{ Model } & Sum of Squares & Df & Mean Square & F & \\
\hline \multirow{3}{*}{1} & Regression & 100.428 & 4 & 25.107 & 52.097 & $.000 \mathrm{~b}$ \\
& & & & & & \\
\cline { 2 - 7 } & Residual & 99.278 & 206 & .482 & & \\
\cline { 2 - 8 } & Total & 199.706 & 210 & & & \\
\hline
\end{tabular}

a. Dependent Variable: Employee Performance

b. Predictors: (Constant), Team Members' Trust, Team Members' Cohesiveness, Team Members' Spirit, Team Members' Knowledge Sharing

\subsubsection{Multiple Regression}

Table 4.4 below shows, the multiple regression analysis of the effect that teamwork on employee performance. Thus, in the table, the regression coefficient for team members' trust of the employee performance in the study's selected private banks $(\beta 1)=0.247$, which implies that one percent increase in team members' trust results into 24.7 percent increment in employees performance level when other variables are controlled. The T value is 3.835 and it's significant at 0.000 since it is less than 0.05 , which is the significance level of this study. This denotes that the alternate hypothesis that says, team members' trust as a measure of teamwork has a significant impact on employee performance in the study's selected private banks in Mogadishu-Somalia is accepted.

The regression coefficient for team members' cohesiveness of the employee performance in the study's selected private banks $(\beta 2)=0.173$, which implies that one percent increase in team members' cohesiveness leads to a 17.3 percent increase in employees performance level when other variables are kept controlled. The $\mathrm{T}$ value is 2.338 , and this is significant at 0.020 because it's less than 0.05 , which is the significance level of current research. Therefore, the alternate hypothesis that says, team members' cohesiveness as teamwork measure has a significant effect on employee performance in the study's selected private banks in Mogadishu-Somalia is accepted. 
The regression coefficient for team members' spirit/esprit de corps of the employee performance in the study's selected private banks $(\beta 3)=0.206$, which means that one percent increase in team members' spirit results into $20.6 \%$ increase in employees performance when other variables are kept constant. The $T$ value is 2.869 , which is significant at .005 as its value is less than 0.05 . Hence, the alternative hypothesis that says, team members' spirit as a measure of teamwork has a significant impact on employees' performance in the study's selected private banks in Mogadishu-Somalia is accepted.

Furthermore, the regression coefficient for team members' knowledge sharing of the employee performance in the study's selected private banks $(\beta 4)=0.217$, which means that a percentage increase in team members' knowledge sharing causes a $21.7 \%$ increase in employee's performance when other variables are kept constant. The $\mathrm{T}$ value is 2.899 , and this is significant at 0.004 since it is less than 0.05 , which is the significance level of this research. Therefore, it indicates that the alternate hypothesis that argues, team members' knowledge sharing as a measure of teamwork has a significant influence on employee performance in the study's selected private banks in Mogadishu-Somalia is accepted. The regression equation below was established by taking all independent variables or teamwork measures into account "e.g. team members' trust, cohesiveness, spirit, and knowledge sharing" constant at zero while employee performance was 0.603.

$\mathrm{EP}=0.603+0.247 \mathrm{TMT}+0.173 \mathrm{TMC}+0.206 \mathrm{TMS} / \mathrm{TMEDC}+0.217 \mathrm{TMKS}+\varepsilon$

Table 4.4. Multiple Regression

\begin{tabular}{|c|c|c|c|c|c|}
\hline \multicolumn{6}{|c|}{ Coefficientsa } \\
\hline \multirow[b]{2}{*}{ Model } & \multicolumn{2}{|c|}{$\begin{array}{c}\text { Unstandardized } \\
\text { Coefficients }\end{array}$} & \multirow{2}{*}{$\begin{array}{c}\text { Standardized } \\
\text { Coefficients }\end{array}$} & \multirow[b]{2}{*}{$\mathrm{T}$} & \multirow[b]{2}{*}{ Sig. } \\
\hline & B & Std. Error & & & \\
\hline $1 \quad$ (Constant) & 0.603 & 0.221 & & 2.722 & 0.007 \\
\hline Team Members' Trust & 0.260 & 0.068 & 0.247 & 3.835 & 0.000 \\
\hline Team Members' Cohesiveness & 0.184 & 0.079 & 0.173 & 2.338 & 0.020 \\
\hline Team Members' Spirit & 0.200 & 0.070 & 0.206 & 2.869 & 0.005 \\
\hline Team Members' ${ }^{\prime}$ Knowledge Sharing & 0.224 & 0.077 & 0.217 & 2.899 & 0.004 \\
\hline
\end{tabular}

a. Dependent Variable: Employee Performance

On the basis of the findings in the above table 4.4, all the null-hypothesis (H0's): “e.g. team members' trust has no significant effect on employee performance, team members' cohesiveness has no significant effect on employee performance, team members' spirit "esprit de corps" has no significant effect on employee performance and team members' knowledge sharing has no significant effect on employee performance in the study's selected private in Mogadishu-Somalia" are rejected at 0.05 level of significance as presented in the 4.5 table below.

Table 4.5. Hypotheses Testing

\begin{tabular}{|c|c|c|c|c|}
\hline Research Hypotheses & B & $\frac{8}{T}$ & Sig. & Comments \\
\hline $\begin{array}{l}\text { HO: Team members' trust has no significant effect on } \\
\text { employee performance }\end{array}$ & 0.247 & 3.835 & 0.000 & Reject $\mathrm{HO}_{1}$ \\
\hline $\begin{array}{l}\mathrm{HO}_{2} \text { : Team members' cohesiveness has no significant } \\
\text { effect on employee performance }\end{array}$ & 0.173 & 2.338 & 0.020 & Reject $\mathrm{HO}_{2}$ \\
\hline $\begin{array}{l}\mathrm{HO}_{s} \text { : Team members' spirit "esprit de corps" has no } \\
\text { significant effect on employee performance }\end{array}$ & 0.206 & 2.869 & 0.005 & Reject $\mathrm{HO}_{3}$ \\
\hline $\begin{array}{l}\mathrm{HO}_{4} \text { : Team members' knowledge sharing has no } \\
\text { significant effect on employee performance }\end{array}$ & 0.217 & 2.899 & 0.004 & Reject $\mathrm{HO}_{\text {s }}$ \\
\hline
\end{tabular}

\section{CONCLUSION}

Based on the findings of this study, the following conclusions were drawn: Hypothesis $\left(\mathrm{H} 1_{1}\right)$ says that team members' trust has a significant effect on employee performance; therefore this study found that the team members' trust has a positive and significant impact on employee performance in the study's selected private banks in Mogadishu-Somalia. The result of hypothesis one is consistent with the previous study of (Manzoor et al., 2011; MBAH, 2014, Agarwal and Adjirackor, 2016; Hassan and Al Salman, 2016; Arinze et al., 2018) who also found that team trust has a positive and significant influence on employee performance. Therefore, it can be concluded that private banks or organizations whose aim is to enhance their employee performance should create an environment that inspires trust among members of their teams since this in return will increase their employee performance as the findings of this study and others indicated.

Hypothesis $\left(\mathrm{H}_{2}\right)$ indicates that team members' cohesiveness has a significant effect on employee performance; therefore this study found that the team members' cohesiveness has a positive and significant impact on employee performance in the study's selected private banks in Mogadishu-Somalia. The outcome of hypothesis two is consistent with (Muthiaine, 2014; Banwo, et al., 2015) who also discovered that team cohesiveness has a positive and significant impact on employee performance. However, this finding is 
inconstant with (Hassan and Al Salman, 2016). Therefore, it can be concluded that organizations willing to enhance their employee performance should make efforts to enhance the cohesiveness among their teams since this will leads to a better performance of their employees as the results of this research discovered.

Hypothesis $\left(\mathrm{H}_{3}\right)$ signifies team members' spirit or "esprit de corps" has a significant impact on employee performance; hence this study revealed that the team members' spirit/esprit de corps has a positive and significant influence on employee performance in the study's selected private banks in Mogadishu-Somalia. The result of the third hypothesis is consistent with the study of (Manzoor et al., 2011; MBAH, 2014; Agarwal and Adjirackor, 2016; Kemanci, 2018; Arinze et al., 2018), nevertheless, this result is inconstant with (Abdullah, 2017). Therefore, private banks ought to know that team spirit will result in better employee performance, so they should establish an atmosphere that motivates and contributes to team spirit among their team members since this will help them increase their employee performance as the outcomes of this study and others discovered.

Hypothesis $\left(\mathrm{H}_{4}\right)$ predicts that team members' knowledge sharing has a positive and significant impact on employee performance, thus this study found that the team members' knowledge sharing has a positive and significant influence on employee performance in the study's selected private banks in Mogadishu-Somalia. This finding is also supported by (Khan \& Mashikh 2017).

In summary, the results of this study revealed that all teamwork measures or independent variables used in this study "e.g. team members' trust, cohesiveness, spirit or esprit de corps and knowledge sharing" have a positive and significant impact on employees' performance in the study's selected private banks in Mogadishu-Somalia. Thus, the private banks in Mogadishu-Somalia should create an environment that assists and inspires teamwork among their team members to enhance trust, cohesiveness, spirit/esprit de corps and knowledge sharing of their team members since this leads to enhance the performance of their employees as the findings of this research indicate.

\section{REFERENCES}

Abdullah, R. (2017). Impact of Teamwork, Esprit De Corps, Team Trust on Employee Performance in Royalindo Expoduta Jakarta Indonesia, 04(03), 106-113.

Agarwal, S., \& Adjirackor, T. (2016). Impact of Teamwork on Organizational Productivity in Some Selected Basic Schools in the Accra Metropolitan Assembly. European Journal of Business, Economics, and Accountancy, 4(6), 40-52. Retrieved from http://www.idpublications.org/wpcontent/uploads / 2016/06/

Al Salman, W., \& Hassan, Z. (2016). Impact of Effective Teamwork on Employee Performance. International Journal of Accounting and Business Management, 4(1), 76-85. https: / / doi.org/10.24924/ijabm/2016.04/v4.iss1/76.85

Banwo, A. O., Du, J., \& Onokala, U. (2015). The Impact of Group Cohesiveness on Organizational Performance: The Nigerian Case. International Journal of Business and Management, 10(6), $146-154$. https: / / doi.org/10.5539/ijbm.v10n6p146

Katzenbach, J. R., \& Smith, D. K. (1993). The wisdom of teams: creating the high-performance organization. New York: Harvard Business School Press. https: / / doi.org/10.1016/j.egypro.2017.08.061

Kemanci, G. (2018). Investigating the Impact of Esprit De Corps/Team Spirit on Employees Performance in the University of Abuja Teaching Hospital, Gwagwalada, Abuja. Nile Journal of Business, and $\begin{array}{lllll}\text { Economics (NileJBE), } & \text { (April), } & \text { Retrieved }\end{array}$ http: / / journal.nileuniversity.edu.ng/index.php/NileJBE/

Khan, D. S., \& Mashikhi, M. L. S. Al. (2017). Impact of Teamwork on Employees Performance. International Journal of Education and Social Science, 4(11), 14-22. https: / / doi.org/10.5296/ bms.v6i1.7804

Manzoor, S. R., Ullah, H., Hussain, M., \& Ahmad, Z. M. (2011). Effect of Teamwork on Employee Performance. International Journal of Learning and Development, 1(1), 110-126. https: / / doi.org/10.5296/ijld.v1i1.1110

MBAH, S. I. (2014). The effects of teamwork on employees' performance: a study of selected firms in Anambra state Nigeria. British Journal of Advanced Academic Research, 3(1), 104-118.

Muthiaine, M. C. (2014). Relationship Between Team Cohesion and Sports Performance Among Basketball Teams in The 2010 National League in Kenya. Graduation Thesis. Kenyatta University.

Phina, N., Arinze, S., Chidi, F., \& Chukwuma, D. (2018). The Effect of Teamwork on Employee Performance: A Study of Medium Scale Industries in Anambra State. International Journal of Contemporary Applied Researches, 5(2), 174-194. 